\title{
A Gender Analysis of Changing Livelihood Activities in the Rural Areas of Central Nepal
}

\author{
Shanta Paudel Khatiwada ${ }^{1,2}$, Wei Deng ${ }^{1,2, *}$, Bikash Paudel ${ }^{3}$, Janak Raj Khatiwada ${ }^{4}(\mathbb{D}$, \\ Jifei Zhang ${ }^{1}$ and Jiangjun Wan ${ }^{5}$ \\ 1 Institute of Mountain Hazard and Environment, Chinese Academy of Sciences, Chengdu 610041, China; \\ shantapaudel@gmail.com (S.P.K.); jfzhang@imde.ac.cn (J.Z.) \\ 2 University of Chinese Academy of Sciences, Beijing 100049, China \\ 3 Local Initiatives for Biodiversity, Research and Development (LI-BIRD), Gairapatan-4, Pokhara 33700, Nepal; \\ bpaudel@libird.org \\ 4 Chengdu Institute of Biology, Chinese Academy of Sciences, Chengdu 610041, China; janak@cib.ac.cn \\ 5 Department of Urban and Rural Planning, Sichuan Agricultural University, Chengdu 610041, China; \\ wanjiangjun@outlook.com \\ * Correspondence: dengwei@imde.ac.cn; Tel.: +86-028-8535-8397
}

Received: 27 September 2018; Accepted: 1 November 2018; Published: 3 November 2018

\begin{abstract}
Gender mainstreaming is a key for achieving inclusive economic growth, poverty reduction and equitable development. A gender disaggregated analysis of changing livelihood activities is, therefore, crucial for devising gender-sensitive policies and programs. This paper presents a gender disaggregated analysis to assess trend and influencing factors of switching livelihood to higher returning activities at the intra-household level in three villages in rural areas of central Nepal. The result showed that both men and women have changed their livelihood activities from subsistence to cash-earning activities in the last decade. However, the livelihood activities of men have changed considerably compared to women. Men are primarily attracted to out-migration and non-farm wage-based jobs whereas women to market-oriented commercial farming and rural enterprises. Individual as well as location-specific characteristics influence behavior switching to higher returning activities irrespective of gender, while the ethnicity of a household influences only women. Building human and financial capital through education and training along with strengthening access to credit and increasing connectivity through rural road and market centers would be pivotal for encouraging rural men and women to change traditional subsistence activities to higher returning undertakings, leading to equitable livelihood improvement in rural Nepal.
\end{abstract}

Keywords: livelihood; change; gender analysis; intra-household; poverty reduction; higher-returning; central Nepal

\section{Introduction}

People's livelihoods are dynamic, involving switches among various strategies depending on time and place [1]. Rural livelihoods in developing countries have been undergoing rapid change in recent decades [2,3]. Newer economic opportunities created by global drivers of change such as globalization, market integration, increasing access to physical facilities, migration, mobility and exposure to modern culture have provided an impetus for spearheading the change in previously adopted livelihood strategies [4-8]. Meanwhile, overexploitation of natural resources and the adverse impact of recent climate change have increased the vulnerability of rural livelihoods by limiting natural resource-based livelihood capital and options $[9,10]$. Consequently, agriculture and natural resource-based rural livelihoods are being increasingly divorced and diversified [11-13]. Hence, livelihood transition due to changing endowments 
of and access to livelihood capital and capabilities triggered by socio-economic, cultural and environmental transformation is obvious in the rural areas of developing countries [5,14-18].

The nature of change in livelihood strategies, however, is not similar across different groups of society, for example, between men and women. Due to differences in the roles and responsibilities and access to livelihood resources, men and women tend to have different livelihood options, adaptation, coping and mitigation strategies [19-22]. Women are likely to have lower access to productive resources, human capital and decision-making due to cultural norms and taboos which limit them to non-economic and unpaid care work within households and family farming [23-25]. Hence, they confront a narrower range of labour markets than men making them more poor, disadvantaged and vulnerable in terms of securing sustainable livelihoods [26-28]. Hence, a prominent difference in changing livelihood activities can be observed between men and women, particularly in developing countries. Nonetheless, only a few studies have focused on changing rural livelihoods and underlying determinants from gender perspectives [26,29-33].

Gender mainstreaming has become a key strategy for achieving inclusive economic growth, poverty reduction and sustainable development, particularly in developing and least-developed countries. It is in essence aiming to create equal economic opportunities for both men and women $[34,35]$. However, the majority of the existing literature on poverty reduction and sustainable livelihoods have treated gender issues at the household level and failed to reflect intra-household gender differences in resource control, access to income-earning activities and bargaining power [25]. Hence, a gender-disaggregated analysis on changing livelihood activities, the pattern of change, preferences and choice of activities and influencing factors is crucial for devising gender-sensitive policies and programs for achieving targeted goals via mainstreaming gender.

Being primarily an agricultural country, agriculture is the mainstay of people's livelihoods and the national economy in Nepal, since more than $65 \%$ of the population is dependent on agriculture for their livelihood, generating one-third (28.8\% in 2016/17) of gross domestic product (GDP) [36]. However, the country endures alarming poverty (22.8\% of the population living in extreme poverty), food insecurity and malnutrition due to higher population growth and low growth in agricultural productivity [37]. Further social inequalities based on gender, class, castes and ethnicity remain high, but are severe in rural areas [37]. Although declared a secular state by the Interim Constitution of Nepal 2007, Nepal is a Hindu-dominated country (more than 80\% Hindu, according to the population census in 2011) with a patriarchal socio-economic structure and cultural norms that are centuries old. Gender discrimination, social exclusion and marginalization have been historically entrenched in the political, economic, and social fabric in Nepal $[34,38]$. Discrimination and exclusion by existing patriarchal institutions (including family, community, society and the state) have caused limited human capital and capabilities among women in Nepal, with a poorer situation in rural households $[34,39,40]$. Limited access to economic activities, productive resources, social networks and decision-making power confined Nepalese women to low-skill, non-market jobs within households, such as care of the family and family enterprises [40-42].

As observed globally, Nepal has also been going through a socio-economic, political and environmental transformation in the recent decade generating both newer opportunities and challenges in rural livelihood [43]. On the one hand, increasing access to road networks, education, electricity, information and communication technologies has been enlarging the non-farm livelihood options locally and outside the villages [37,42]. Concurrently, growing connectivity to global markets, trade and technologies have been expanding new economic potential such as tourism and micro-enterprises even in remote areas in Nepal $[44,45]$. By contrast, accelerated environmental resource degradation caused by increasing pressure on land, water and forest resources has been limiting natural resource-based livelihood portfolios in Nepal. Alongside this, adverse impacts of ongoing climate change have been declining economic potentials from agriculture in rural areas that depend on rain-fed irrigation [46,47]. Adding to this, there are gradual omissions of social taboos imposed on women, and transformations in traditional gender roles, responsibilities, power-relation and decision-making power [38,39]. 
Given these changing scenarios, the livelihood activities of rural people in Nepal are also in transition [13,48,49]. Shrinking economic potential in agriculture due to limited arable land, low productivity and the adverse impact of climate change have forced people to find additional income sources [46,47]. In addition to subsistence agriculture, seasonal and long-term migration to cities and abroad, self-employment in rural enterprises and tourism have become important sources of income in rural households [48,50-52]. Likewise, many rural households living near markets and roads have intensified farming by growing market-oriented cash crops and keeping livestock [53-55]. The advent of newer livelihood activities has brought several positive changes in national-level socio-economic status in the recent decades in Nepal. The national statistics show that the contribution of agriculture in the national economy has been a decreasing trend (from 47.7\% of GDP in 1990/91 to $37.1 \%$ in $2010 / 11$ and $28.8 \%$ in 2016/17) [36,56]. Similarly, the share of remittances in GDP has increased from $13.8 \%$ in 2006/07 to 29.6 in 2015/16 [36]. Furthermore, the proportion of households operating non-farm enterprises has increased from 24 to 35\% between 1995/96 and 2010/11 [57]. Nepal has achieved a significant decreasing trend in aggregate poverty in recent decades $(42 \%$ in 1996 and $21.6 \%$ in 2015) [37,57]. In addition, there have been improvements in social indicators such as education, health and nutrition, sanitation, drinking water and gender and social inequality [37,57]. Moreover, there has been a gradual shift in the traditionally shaped social relations, traditional gender roles, and power relations, decision-making and household structures in rural Nepal [52,58].

Despite these changes in income strategies, considerable differences exist in the selection of a particular livelihood activity between men and women. Existing studies related to poverty and livelihood in Nepal have revealed that Nepalese women are poorer and more vulnerable to the adverse impact of climatic and other shocks due to their limited adaptive capacity and lower income compared to men $[9,22,58]$. Moreover, women are facing increased food deficiency due to the increasing feminization of agriculture triggered by male out-migration and their increasing role in low-return subsistence agriculture [59]. Therefore, improving women's involvement in productive and income-generating activities is important for their economic empowerment and fostering equitable economic development in Nepal. However, there is dearth of studies evaluating the difference in income-generating activities adopted by men and women, patterns and determinants of change which are very important for formulating gender inclusive economic growth and poverty reduction plans in Nepal.

In this context, this study aims to analyze the pattern and determinants of changing livelihood activities in the agricultural setting in the central landscape of Nepal through a gender-disaggregated analysis. Specifically, this study aims to: (1) conduct a gender-disaggregated analysis of changing livelihood activities for men and women in the last decade; (2) to assess the patterns of changing livelihood activities for men and women; and (3) to identify the influencing factors for switching to higher-returning activities by men and women. Unlike previous studies, the findings of the study contribute to literature with gender-disaggregated analysis of changing livelihood activities and determinants at the individual level. In addition, incorporating a perspective on how livelihood activities have changed and been adapted differentially by men and women in the changing context can aid policy makers in designing and evaluating poverty reduction and gender-sensitive livelihood-enhancement programs.

\section{Materials and Methods}

\subsection{Conceptual Framework}

This study used DFID's (Department For International Development) Sustainable Livelihood Framework (SLF) to assess the change in the livelihood activities by males and females in rural households in central Nepal. A livelihood comprises the assets, the activities and the capabilities that together determine the living gained by the individual or households including food, income and assets. Livelihood is sustainable when people can cope with and recover from stress and shocks and maintain or enhance their capabilities and assets without undermining the natural resource 
base [60]. The sustainable livelihood approach by employing the SLF has become a dominant tool among researchers and development practitioners in poverty reduction and livelihood improvement particularly in the rural areas of developing countries. SLFs directly link the assets as an input to pursue a range of income-generating activities for survival and for improving wellbeing. The input resources in terms of livelihood assets are dynamic in nature and their access is mediated by the social institution and power relations, including gender [1]. Most of the existing literature on poverty and livelihood treated the household as a unit of analysis and combined various economic activities into a particular livelihood strategy at the household level [61,62]. However, in practice, everyone in the households may have different bargaining power in accessing and controlling different types of assets and may have pursued different activities to make their living [29,63,64]. Such intra-household inequalities in economic control, interest, and opportunities which often have gender as a basis, are not given enough attention. We selected DFID's SLF framework among others, because it has included gender and power relations as one aspect of the transforming process and highlighted the need to give particular attention to disaggregated analysis based on gender and different social groups $[62,65]$.

\subsection{Study Area}

This study was carried out in three Village Development Committees (VDCs) namely Bachhauli, Ghyalchok, and Ghanapokhra from Chitwan, Gorkha, and Lamjung districts in the central landscape of Nepal (Figure 1). The study villages are located at different elevation ranges from Bachhauli (below 200 meters above sea level, masl) to Ghyalchok (350-1400 masl) and Ghanpokhara (1500-2700 masl). The three villages represent three agro-ecological regions of Nepal (inner-terai, mid-hill, and high-hill) [48,66]. Smallholder subsistence farming characterized by mixed crop-livestock production systems, salaried jobs, out-migration to cities and abroad, and wage labour are the major and common income activities in the area $[48,67]$.

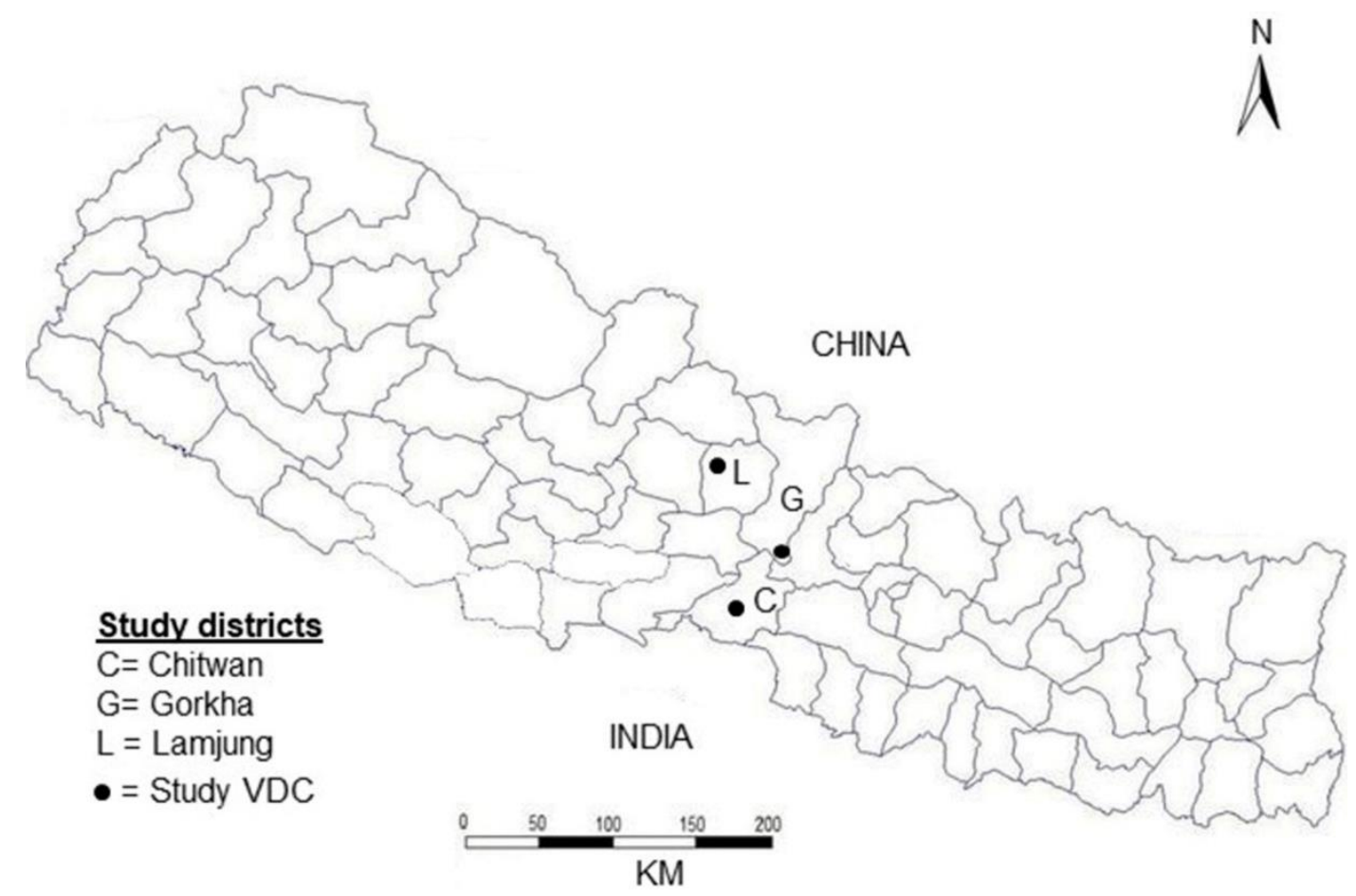

Figure 1. Map of Nepal showing the study districts with the selected sampling Village Development Committee (VDC).

Along with socio-economic and cultural transformation, progress on infrastructure such as rural road and electricity, communication and information technologies, education and health facilities in recent decades, particularly after the peace agreement ending 10 years of armed conflict in 2006 [42], 
in the selected villages means they are also experiencing a huge contextual change providing newer opportunities and constraints to households and individual livelihoods. Consequently, villagers are increasingly involved in newer economic activities such as market-oriented food and cash-crop farming, livestock production, non-farm business/enterprises and tourism-related activities [48]. The evolving socio-cultural and economic context has been increasing women's roles and responsibilities in the household economy and construction of livelihoods. Despite this, various patriarchal institutions and norms still exist, maintaining a subordinated position of women within and outside households that undermines their capital and capabilities where the degree of subordination varies by caste/ethnicity and religion (38-41). The three sites are also rich in ethnic composition including Brahmin, Chhetri, Dalit, Gurung, Newar, Tharu, Magar, Lama, Tamang, Ghale etc. representing the livelihood transition of men and women in multiple ethnic groups.

\subsection{Data and Sampling}

We used data generated through a questionnaire survey followed by a series of formal and informal interviews and group discussions conducted in the study villages from November to December 2015. Prior to the household survey, several informal key informant interviews, three focus group discussions (FGDs) (one in each VDC), and 12 key informant surveys (four in each VDC) were conducted to better understand the contextual and livelihood activity changes in the past decade. Each FGD contained 15-20 participants comprising old farmers, local leaders, government officers, and development workers as representatives, while key informants included local shopkeepers, local teachers, and government officers. Both men and women (about $50 \%$ of each) were included as key informants and representative of FGD. Finally, the questionnaire survey was administered following multi-stage random sampling with a pretested set of questionnaires. Out of nine wards, four wards in Bachhauli and Ghanpokhara and five wards in Ghyalchok were purposively selected so that livelihood variation in the selected VDCs is captured by the study. A total of 453 households (about $10 \%$ of the total households in three VDCs) comprising 217 households from Bachhauli, 133 from Ghyalchok, and 103 from Ghanapokhra were randomly selected for the household survey. The survey collected information regarding the changes in the livelihood strategies by members of the household along with individual characteristics including age, sex, occupation, relation to household head, marital status, education, skills development training, membership in the organization, out-migration. Moreover, household characteristics including family type, religion, ethnic affiliation and distance to road and local market center were also collected through the household survey.

\subsection{Data Analysis}

\subsubsection{Assessing Current Livelihood Activities by Gender}

More than 25 types of livelihood activities were recorded from the survey. For the simplicity of the analysis, these livelihood activities were categorized into nine broad categories. They included farming (includes food crop production, cash crop production and livestock production); business/enterprises (includes trading, self-employed income-generating activities, livestock enterprises, artisanship); foreign job; salaried job (includes civil service, job in private or public organizations); wage labour non-agriculture; wage labour agriculture; student; dependent; and unemployed. A chi-square test was used to examine the differences in the selection of the main livelihood activities disaggregated by gender. Frequencies and percentages of the main livelihood activities involving men and women were derived separately from the presence and absence of data.

\subsubsection{Assessing Changes in Livelihood Activities, Reasons and Pattern by Gender}

For gender-disaggregated change in the livelihood activities, the frequencies and percentages of men and women involved in various livelihood activities in 2015 (current) were compared with their main livelihood activities 10 years previously. Out of 2532 individuals from 453 households covered 
by this survey, 1990 individuals having the age of more than 15 years were used to assess the change in livelihood activities. Out of the total individuals included in the analysis, 1003 (50.4\%) were men and 987 (49.6\%) were women. The categories of the nine broad livelihood activities classified above were used for assessing the changes.

Ideally, studying livelihood strategy repeated in a different point in time over several years assesses the changes in livelihood strategies more effectively. Given that the data used in this study were from cross-sectional surveys, a recall-based questionnaire was used to assess the changes in livelihood activities. Longer reference times in the recall-based survey, particularly in the survey related to income and expenditure, are subject to errors due to the memory failure of respondents [68]. However, the purpose of this study is to explore the trend of change in livelihood activities rather than changes in real income and expenditure. Hence, following Kristjanson's study [69], we considered a 10-year reference time for recalling the information. Moreover, the reference year (i.e., 2006) is memorable in the history of Nepal because it was the end of a decade-long Maoist insurgency and the beginning of the New Republic of Nepal. It is the most effective point of time for recalling the livelihood activities for them. The questionnaires included questions like: did any member of your family change income activities from 10 years ago? If yes, who changed? From which activity to which? Why did they change? Furthermore, qualitative information from FGDs and key informants' surveys provided complementary information to assess the changes in livelihood activities.

\subsubsection{Exploring the Influencing Factors to Change to Higher-Returning Strategies}

To explore the factors influencing the change to higher-returning activities, binary logistic regressions were used separately for men and women. Following the findings of Paudel Khatiwada [48] conducted in the same area, this study included two livelihood activities i.e., business/rural enterprises and commercial farming as higher-returning activities, while out-migration, wage-based and subsistence farming were lower-returning activities. The dependent variable was binary $[1,0]$ which was defined as " 1 " if an individual has shifted from any of the three aforementioned lower-returning activities to any of the higher-returning activities in the past 10 years, and " 0 " otherwise.

Altogether, 15 explanatory variables were used in the binary logistic regression model. The definitions and expected influence of these variables on shifting to higher-returning activities are presented in Table 1. The variables included household, individual and geographic/location characteristics, particularly from human and social capital. A household's characteristics included sex of household head, family type, ethnicity and religion, while individual characteristics included age, education, relationship to household head, marital status, skill and training, membership in formal or informal group/organization, access to credit and migration/mobility. Similarly, variables including agroecology, distance from home to the nearest market, and distance from home to the nearest road were used as geographic/location characteristics. No collinearity $(r<0.70)$ among the explanatory variables was observed in regard to the men, while there was strong multicollinearity $(r>0.70)$ between marital status and relationship to household head for women, hence marital status was not included in the binary logistic regression for the analysis of women. 
Table 1. Variables used in the binary logistic regression model to explore determinants of livelihood activity changes to higher-returning activities by males and females.

\begin{tabular}{|c|c|c|c|}
\hline Variable & Definition & Hypothesized Effect & Literature Review \\
\hline \multicolumn{4}{|l|}{ Individual characteristics } \\
\hline Age & Age of individuals (years) & $+/-$ & [70-72] \\
\hline Education & Individual's years of schooling (years) & $+1-$ & {$[33,70,73]$} \\
\hline Relation to household head $(\mathrm{HH})$ & $\mathrm{HH}$ head $=1$; Spouse of $\mathrm{HH}$ head $=2 ;$ son $/$ daughter, grandson $/$ granddaughter $=3$; daughter-in-law $=4$ & $+1-$ & [74] \\
\hline Marital status & Whether the individual is married; Dummy; Other $=0$ Married $=1$ & + for both & {$[31,71,75]$} \\
\hline Skill training & Whether the individual has income generating training; Dummy; $\mathrm{No}=0$; Yes $=1$ & + for both & {$[72,76]$} \\
\hline Membership in organization & Whether the individual has membership in formal/informal groups/organizations; Dummy; No =0; Yes = 1 & + for both & {$[70,77]$} \\
\hline Out-migration/mobility & If the individual out-migrated to city or abroad; Dummy; $\mathrm{No}=0 ; \mathrm{Yes}=1$ & + for both & \\
\hline Access to credit & If the individual has a loan (Dummy; $\mathrm{Yes}=1, \mathrm{No}=0$ ) & + for both & {$[70,78,79]$} \\
\hline \multicolumn{4}{|l|}{ Household characteristics } \\
\hline Family type & Nuclear family $=1$; joint family $=2$ & + (for women in nuclear family) & {$[80,81]$} \\
\hline Ethnicity & Household's ethnic affiliation Dalit $=1 ;$ Janajati $=2 ;$ Tharu $=3 ;$ Brahmin $/$ Chhetri $=4$ & +/for Brahmin/Chhetri & {$[48,77,82,83]$} \\
\hline Religion & Religious affiliation of households; $0=$ others; Hindu $=1$ & + for Hindus & [13] \\
\hline \multicolumn{4}{|l|}{ Geographic Location } \\
\hline Distance to road & Distance from home to nearest vehicle passable road & - & {$[48,79,84]$} \\
\hline Distance to market & Distance from home to local market center & - & {$[48,79,84]$} \\
\hline Agroecology & Low-land terai Village Development Committee $(\mathrm{VDC})=1$; Mid-hill VDC $=2$; and high-hill VDC $=3$ & $+1-$ & {$[48,78]$} \\
\hline
\end{tabular}

+ refers to positive effect and - refers to negative effect. 


\section{Results and Discussion}

\subsection{Comparing Current Livelihood Activities by Gender}

Gender disaggregated analysis of current livelihood activities in Table 2 indicated strong gender differences in the selection of the five livelihood activities out of nine in overall. A significantly higher proportion of men were involved in business and enterprise $\left(\chi^{2}=11.4 ; p=0.001\right)$, salaried job $\left(\chi^{2}=53.1\right.$; $p=0.001)$, foreign job $\left(\chi^{2}=180.20 ; p=0.001\right)$, and wage labour non-agriculture $\left(\chi^{2}=55.9 ; p=0.001\right)$ compared to women. On the contrary, a significantly higher $\left(\chi^{2}=320.16 ; p=0.001\right)$ percentage of women (about 49\%) than men (about 16\%) followed farming as the major livelihood activity. Almost similar percentages of men and women were found to be students indicating the somewhat equal access to education for both boys and girls. Similarly, the number of dependent men were significantly higher $\left(\chi^{2}=5.25 ; p=0.05\right)$ than women overall. Likewise, a higher percentage of men $(1.5 \%)$ were unemployed than women $(0.6 \%)$. The disaggregated analysis of current livelihood activities by men and women in each study site also indicated a similar trend (Table 2). The result showed that significantly higher proportions of men followed foreign job, salaried job and wage labour non-agriculture activities compared to women (Table 2). Similarly, the proportions of men engaged in business/enterprise activities were significantly higher in Mid-hill and High-hill villages. However, there was a significantly higher number of dependent men in the High-hill site (Table 2). However, engagement of women in farming was significantly higher than men in all the three sites (Table 2).

The result has indicated that higher percentages of men are involved in cash-earning activities and women in farming. The result indicating women's domination in farming activities and men's supremacy in non-farm activities is certainly not new. Zakaria's study [30] in Ghana also concluded with significantly higher number of women engaged in farm-based livelihoods activities. The reasons behind this could be due to lower access to livelihood capital including less access to education and training (85), limited access to productive assets such as financial capital [39,85], persistence of socio-cultural norms ascribing women to unpaid care work, and limited mobility due to burdened family responsibility [40]. With all these economic and social constraints, women tend to take responsibility for household deeds and farm-based livelihood activities.

\subsection{Comparing Change in Livelihood Activities by Gender}

There is a clear difference in the pattern of change in livelihood activities between men and women in the study sites. Out of total 1990 people above 15 years (1003 men and 987 women), 510 men and 146 women have changed their main income-generating activities within the past decade. However, a significantly higher percentage of men $(50.9 \%)$ have changed their main income activity than women $(14.8 \%)\left(\chi^{2}=292.6 ; p=0.001\right)$. The result indicated a noticeable increase in the percentage of men and women who engage in self-employed business/enterprises, commercial farming, foreign job, and non-farm salaried jobs and a sharp decrease in subsistence farming and wage laboring in agriculture, irrespective of the gender. Little difference was observed between the trend of agricultural laboring between men and women, where the percentage of men changing to agricultural laboring as the main livelihood activity has gone down but the percentage of women doing agricultural laboring has gone up slightly.

Among the men who have changed their livelihood strategies in last decade, the highest (41\%) have followed foreign jobs as their major source of income at present, which was a main income source for $3.4 \%$ of them 10 years previously (Figure 2). Similarly, the percentage of men who changed their income activities to non-farm salaried jobs was $23 \%$, which was about $8 \%$ in the past. The percentage of men who are engaged in commercial farming has increased from about 5\% to $15 \%$ during past decade and the percentage of men undertaking self-employed business and enterprise as a main income activity rose 3\% to $14 \%$ during same period. However, involvement of the men in subsistence farming has decreased significantly from $28 \%$ to about $3 \%$ in the last 10 years (Figure 2a). 
Table 2. Engagement in major livelihood activities by gender. Numbers in parenthesis are the percentages. Results are derived from chi-square test.

\begin{tabular}{|c|c|c|c|c|c|c|c|c|c|c|c|c|}
\hline \multirow[b]{2}{*}{ Livelihood Activities } & \multicolumn{3}{|c|}{ Inner-Terai } & \multicolumn{3}{|c|}{ Mid-Hill } & \multicolumn{3}{|c|}{ High-Hill } & \multicolumn{3}{|c|}{ Overall } \\
\hline & $\begin{array}{c}\text { Men } \\
(\mathrm{N}=610)\end{array}$ & $\begin{array}{c}\text { Women } \\
(N=578)\end{array}$ & Chi-Square & $\begin{array}{c}\text { Men } \\
(\mathrm{N}=374)\end{array}$ & $\begin{array}{c}\text { Women } \\
(\mathrm{N}=378)\end{array}$ & Chi-Square & $\begin{array}{c}\text { Men } \\
(\mathrm{N}=316)\end{array}$ & $\begin{array}{l}\text { Women } \\
(\mathrm{N}=276)\end{array}$ & Chi-Square & $\begin{array}{c}\text { Men } \\
(\mathrm{N}=1300)\end{array}$ & $\begin{array}{c}\text { Women } \\
(\mathrm{N}=1232)\end{array}$ & Chi-Square \\
\hline Business/enterprise & $46(7.5)$ & $32(5.5)$ & 1.94 & $26(7.0)$ & $10(2.6)$ & $7.65 * *$ & $25(7.9)$ & $11(4)$ & $3.98 *$ & $97(7.4)$ & $53(4.3)$ & $11.46^{* * *}$ \\
\hline Farming & $91(14.9)$ & $283(49)$ & $159.46^{* * *}$ & $74(19.8)$ & $170(45)$ & $54.41^{* * *}$ & $41(13)$ & 151(54.7) & $117.10^{* * *}$ & 206(15.8) & $604(49.1)$ & $320.16^{* * *}$ \\
\hline Foreign job & $97(15.9)$ & $6(1)$ & $82.80^{* * * *}$ & $34(9.1)$ & $7(1.9)$ & $19.11^{* * *}$ & $79(25)$ & $0(0)$ & $79.63^{* * *}$ & $210(16.1)$ & $13(1.1)$ & $180.20^{* * *}$ \\
\hline Salaried job & $100(16.4)$ & $36(6.2)$ & $30.25^{* * *}$ & $56(15)$ & $12(3.2)$ & $31.82^{* * *}$ & $14(4.4)$ & $11(4)$ & 0.07 & $170(13.0)$ & $59(4.8)$ & $53.18^{* * *}$ \\
\hline Wage labour non-agriculture (WLNA) & $31(5.1)$ & $0(0)$ & $30.16^{* * *}$ & $15(4)$ & $1(0.3)$ & $12.67^{* * *}$ & $20(6.3)$ & $2(0.7)$ & $12.93^{* * *}$ & $66(5.0)$ & $3(0.2)$ & $55.93^{* * *}$ \\
\hline Wage labour agriculture (WLA) & $2(0.3)$ & $7(1.2)$ & $3.08 *$ & $1(0.3)$ & $1(0.3)$ & 0.12 & $3(0.9)$ & $2(0.7)$ & 0.09 & $6(0.5)$ & $10(0.8)$ & 11.22 \\
\hline Student & $166(27.2)$ & $140(24.2)$ & 1.39 & $113(30.2)$ & $128(33.9)$ & 1.15 & $85(26.9)$ & $66(23.9)$ & 0.7 & $364(27.9)$ & $334(27.1)$ & 0.3 \\
\hline Unemployed & $8(1.3)$ & $3(0.5)$ & 0.27 & $3(0.8)$ & $5(1.3)$ & 0.87 & $9(2.8)$ & $0(0)$ & 0.07 & $161(12.4)$ & $148(12.0)$ & 0.02 \\
\hline Dependent & $69(11.3)$ & $71(12.3)$ & 2.03 & $52(13.9)$ & $44(11.6)$ & 0.48 & $40(12.7)$ & $33(12.0)$ & $7.98^{* *}$ & $20(1.5)$ & $8(0.6)$ & $5.25^{* *}$ \\
\hline
\end{tabular}


Among the women who have changed their income activities, the highest number of females (about 29\%) have shifted to self-employed business/enterprise activities, which was the main income activity for a relatively low percentage (2.7\%) of women 10 years previously (Figure $2 b$ ). About $25 \%$ of the women have shifted their major income activity to commercial farming, which was only $4.8 \%$ before. Women's involvement in foreign jobs has also increased from $0.7 \%$ to $8.9 \%$ during this period. Although permitted by law, women's independent out-migration is yet not easily accepted in rural households. Hence, fewer women $(8.9 \%)$ are engaged in a foreign job compared to men. Therefore, the majority of women who reported foreign job as their main income might have migrated with their husbands or other family members rather than as independent labour. There is a tremendous increase in the number of women involved in salaried jobs, which has risen from $2.7 \%$ to $24 \%$ within 10 years. The percentage of women practicing subsistence farming as a major livelihood activity has reduced sharply from $44.5 \%$ to $10.2 \%$ in the last decade (Figure $2 \mathrm{~b}$ ).

Overall, as indicated by the result, people in the study villages, irrespective of gender, have been shifting their subsistence-oriented livelihood activities to cash-earning activities. This result corroborates with Bhandari's [13] study who also found that rural people in Nepal have been shifting their farming activities to non-farm diversification. Decreasing profit from subsistence farming, newer livelihood opportunities due to increasing access to infrastructure and technology, and education and skills development training in the rural areas could be some of the reasons for the diversion of rural people from subsistence farming. The results show a strong good indication regarding the improvement in the livelihood of women in society. For example, there is a steady increase in the percentage of women involved in salaried jobs during the last 10 years. This progress can be attributed to the increased level of women's education and various affirmative actions and positive discrimination in favour of women in the workforce and the adoption of gender-friendly environments in the workplace.

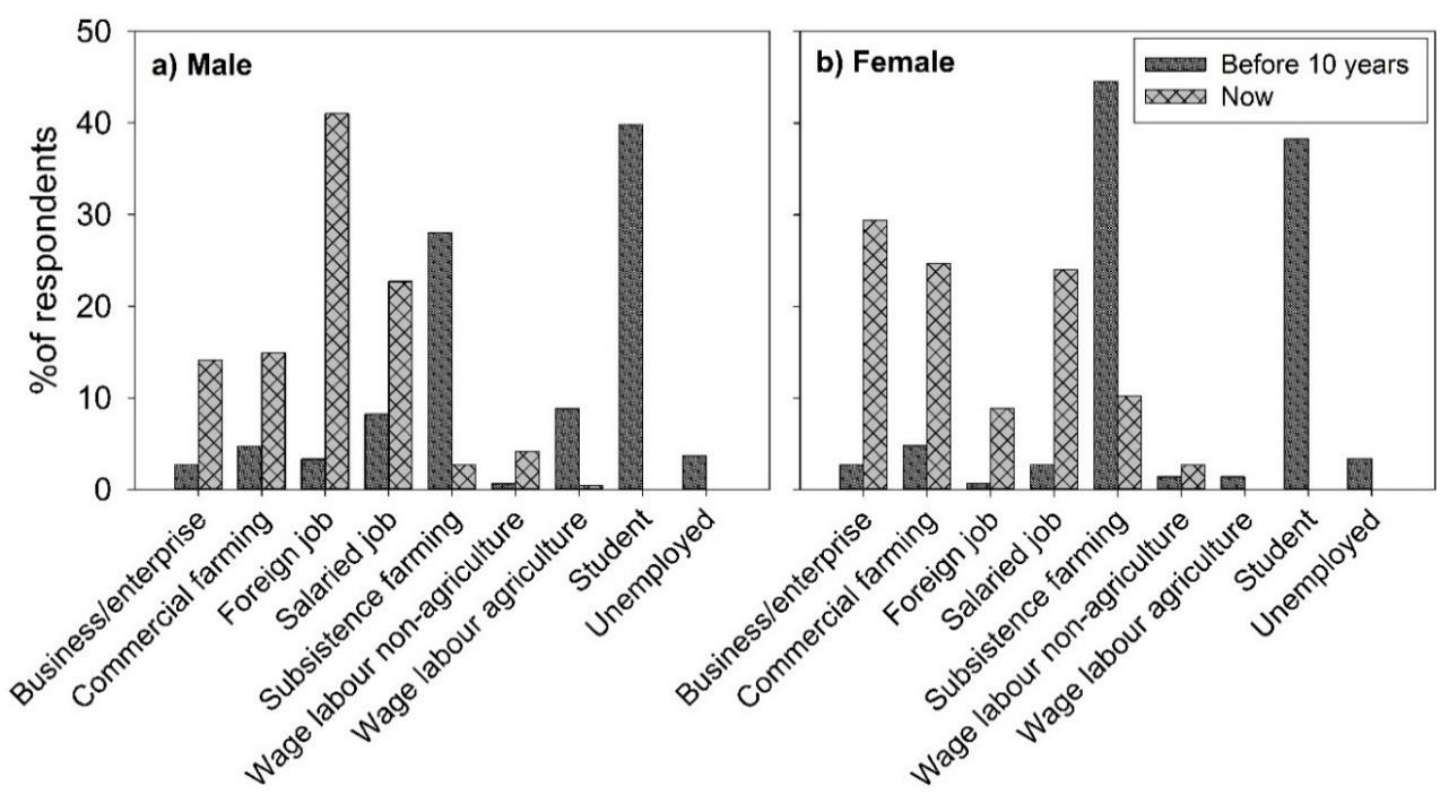

Figure 2. Livelihood activities engaged by males (a) and females (b) at present and 10 years previously. The percentage are derived from the total number of males $(\mathrm{N}=510)$ and females $(\mathrm{N}=146)$ who changed their income activities to those of 10 years previously.

\subsection{Patterns of Livelihood Activity Change by Gender}

This study further assessed the patterns of changing income activities by economically active men and women (Table 3). The result showed that about $43 \%$ of the men who used to do business/enterprise have changed their major activity to foreign jobs followed by salaried jobs $(21 \%)$ and commercial farming $(21 \%)$. Out of the total men who used to do commercial farming 10 years before, $25 \%$ of them 
changed to business/enterprise and salaried jobs while equal percentages (about 21\%) shifted into foreign jobs and subsistence farming. More than half (about 53\%) of the men who used to engage in foreign jobs have shifted to self-employed business/enterprise activities while equally about $18 \%$ have switched into commercial farming and salaried jobs. Similarly, more than half (about 52\%) of the men who used to have salaried jobs before shifted to foreign jobs. The highest proportion (about $36 \%$ ) of the men whose major income activity was subsistence farming modified into commercial farming, while about $33 \%$ of men migrated to take foreign jobs. More than three fourths $(77.8 \%)$ of the men who used to engage in wage labour in the non-agriculture sector shifted to foreign jobs. Out of total students $(\mathrm{N}=203)$ in the past, about $41 \%$ have been involved in salaried jobs followed by $39 \%$ in foreign jobs. Likewise, about $69 \%$ of the unemployed men 10 years before had chosen foreign jobs as their main income source at present (Table 3).

In the case of females, the result indicated that $50 \%$ of the females who used to engage in self-employed business/enterprise 10 years before changed to salaried jobs followed by commercial farming $(25 \%)$ and subsistence farming (25\%). All the females who used to engage in commercial farming, foreign jobs, wage labour in the agriculture sector and wage labour in the non-agriculture sector a decade before shifted their activities into subsistence farming at present. Three fourths of the females who used to engage in salaried jobs before are involved in foreign jobs while about one-fourth of them are doing subsistence farming. More than half of the women (51\%) whose major livelihood activity was subsistence farming 10 years before shifted to commercial farming while more than one third (about $37 \%$ ) have shifted to self-employed business and enterprise activities. Out of total girl students $(\mathrm{N}=57)$ in the past, almost half (about $47 \%$ ) are involved in salaried jobs followed by $32 \%$ in business/enterprise and $16 \%$ in foreign jobs at present (Table 3 ).

Furthermore, analysis of switching livelihood activities to higher-returning activities in Table 4 showed that out of 510 men and 146 women, 148 (29.1\%) men and 79 (54.1\%) women have changed their lower or no cash-returning activities for the sake of higher-returning ones. Among them, the majority $(48 \%)$ of the men and $(72 \%)$ of the women have changed subsistence farming to higher cash-earning activities. Similarly, about $21 \%$ of the young boys who used to be students have started higher cash-earning activities at present, while about $25 \%$ of girl students have.

As indicated by the results, non-farm-based income activities (particularly foreign jobs and non-farm wage activities including salaried jobs) have become the center of attraction for most of the men in the study villages. Regarding women, they are increasingly switching from subsistence to business/enterprise and commercial farming activities, particularly vegetable and livestock farming enterprises, along with self-employed income-generating activities. Although a higher percentage of women have switched to higher-returning activities, the actual numbers of women who have changed their livelihood activities is fewer than men. Out-migration has become the first choice of the majority of the younger men while women are increasingly forced to carry out family business/enterprises and market-oriented vegetable and livestock production. This result is consistent with Bushel's [86] findings in Nepal and Sati and Juyal's [87] finding in India which also concluded thats despite the constraints and entry barriers, women's involvement in rural enterprises and market-oriented farming has been increasing in recent years. The increasing economic participation of women, on the one hand, has been decreasing their dependencies on subsistence farming and increasing their economic empowerment. However, at the same time, it has increased women's drudgery and may have consequences for their health [88]. For instance, women's involvement in commercially-oriented vegetable production has made them more vulnerable to health hazards due to increasing workloads and the negative impacts of pesticides and insecticides. 
Table 3. Livelihood activities' changing patterns by males and females. The numbers in the table are percentages. Percentages are based on the total number of individuals involved in each activity at present and 10 years previously. $\mathbf{M}$ represents $\mathbf{M e n}$; $\mathbf{W}$ represents Women and $\mathbf{N}$ represents the total number of individuals involved in each activity 10 years before.

\begin{tabular}{|c|c|c|c|c|c|c|c|c|c|c|c|c|c|c|c|c|c|c|c|}
\hline & & \multicolumn{18}{|c|}{ Livelihood Activities before 10 Years } \\
\hline & & \multicolumn{2}{|c|}{ Business/Enterprise } & \multicolumn{2}{|c|}{ Commercial Farming } & \multicolumn{2}{|c|}{ Foreign Job } & \multicolumn{2}{|c|}{ Salaried Job } & \multicolumn{2}{|c|}{ Subsistence Farming } & \multicolumn{2}{|c|}{ WLNA } & \multicolumn{2}{|c|}{ WLA } & \multicolumn{2}{|c|}{ Student } & \multicolumn{2}{|c|}{ Unemployed } \\
\hline & & $\mathbf{M}$ & W & $\mathbf{M}$ & W & $\mathbf{M}$ & W & $\mathbf{M}$ & W & $\mathbf{M}$ & $\mathbf{W}$ & $\mathbf{M}$ & $\mathbf{W}$ & $\mathbf{M}$ & $\mathbf{W}$ & $\mathbf{M}$ & $\mathbf{W}$ & $\mathbf{M}$ & W \\
\hline & & $\mathrm{N}=14$ & $\mathrm{~N}=4$ & $\mathrm{~N}=24$ & $\mathrm{~N}=7$ & $\mathrm{~N}=17$ & $\mathbf{N}=\mathbf{1}$ & $\mathrm{N}=42$ & $\mathrm{~N}=4$ & $\mathrm{~N}=143$ & $\mathrm{~N}=65$ & $\mathrm{~N}=45$ & $\mathrm{~N}=4$ & $\mathrm{~N}=3$ & $\mathbf{N}=3$ & $\mathrm{~N}=\mathbf{2 0 3}$ & $\mathrm{N}=57$ & $\mathrm{~N}=19$ & $\mathrm{~N}=5$ \\
\hline \multirow{7}{*}{ 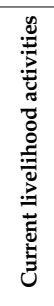 } & Business/enterprise & 0 & 0 & 25 & 0 & 52.9 & 0 & 11.9 & 0 & 13.3 & 36.9 & 15.6 & 0 & 0 & 0 & 11.8 & 31.6 & 10.5 & 40 \\
\hline & Commercial farming & 21.4 & 25 & 0 & 0 & 17.6 & 0 & 21.4 & 0 & 36.4 & 50.8 & 2.2 & 0 & 33.3 & 0 & 3.4 & 1.8 & 0 & 20 \\
\hline & Foreign job & 42.9 & 0 & 20.8 & 0 & 0 & 0 & 52.4 & 75 & 32.9 & 1.5 & 77.8 & 0 & 33.3 & 0 & 39.4 & 15.8 & 68.4 & 0 \\
\hline & Salaried job & 21.4 & 50 & 25 & 0 & 17.6 & 0 & 0 & 0 & 11.2 & 6.2 & 4.4 & 0 & 0 & 0 & 40.9 & 47.4 & 15.8 & 40 \\
\hline & Subsistence farming & 0 & 25 & 20.8 & 100 & 11.8 & 100 & 14.3 & 25 & 0 & 0 & 0 & 100 & 33.3 & 100 & 0 & 1.8 & 0 & 0 \\
\hline & WLNA & 14.3 & 0 & 8.3 & 0 & 0 & 0 & 0 & 0 & 4.9 & 4.6 & 0 & 0 & 0 & 0 & 4.4 & 1.8 & 5.3 & 0 \\
\hline & WLA & 0 & 0 & 0 & 0 & 0 & 0 & 0 & 0 & 1.4 & 0 & 0 & 0 & 0 & 0 & 0 & 0 & 0 & 0 \\
\hline
\end{tabular}


Table 4. Livelihood activities switch to higher-retuning and other activities by males and females. The figures in parentheses are percentages. Percentages are derived from the total number of males and females among the adopters and non-adopters of higher-returning activities.

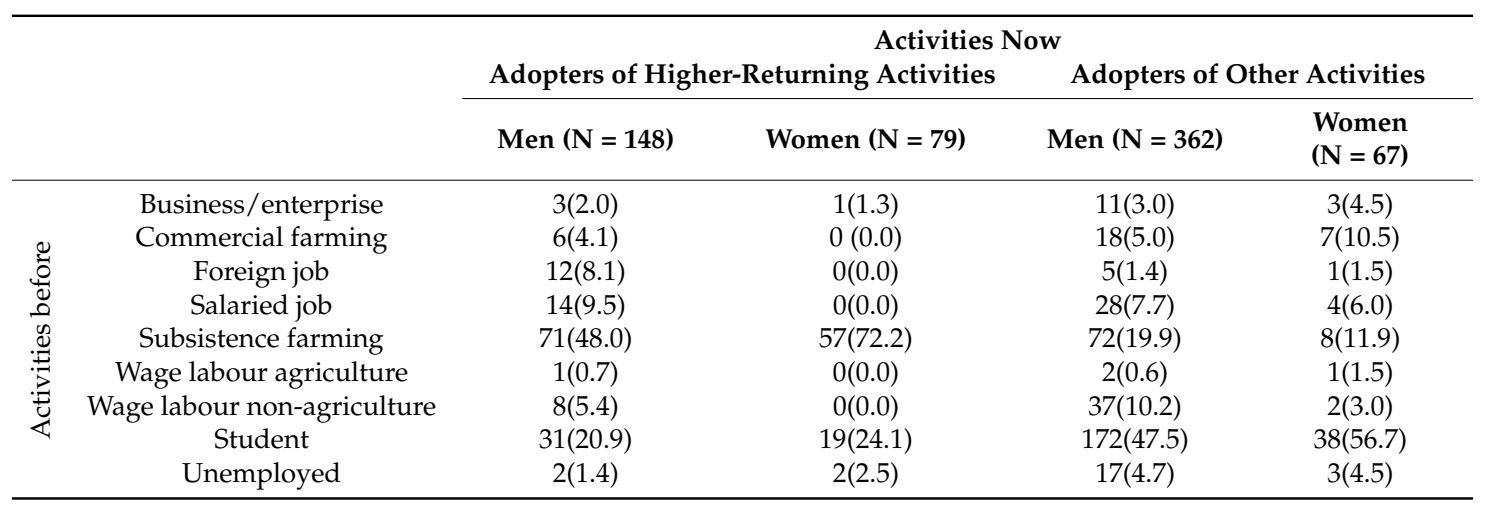

\subsection{Reasons for Changing Income Activities by Gender}

Based on the answers from respondents, 16 reasons were identified as the major reasons for changing livelihood activities by men and women. Among them, a total of 11 major reasons (including the need to increase income, low income from subsistence farming, no job available in the village, old age/pension, sickness/diseased, loss in previous activities, collapse of previous office/company, lack of household labour, migration and marriage) tend to force rural people to find alternative livelihood activities. A higher profit, increasing access to the market and vehicle-passable roads, easier access to credit, and increased academic qualification/skills/training were the factors which have encouraged rural people to change their livelihood activities. The gender-disaggregated reasons for changing livelihood activities are presented in Figure 3.

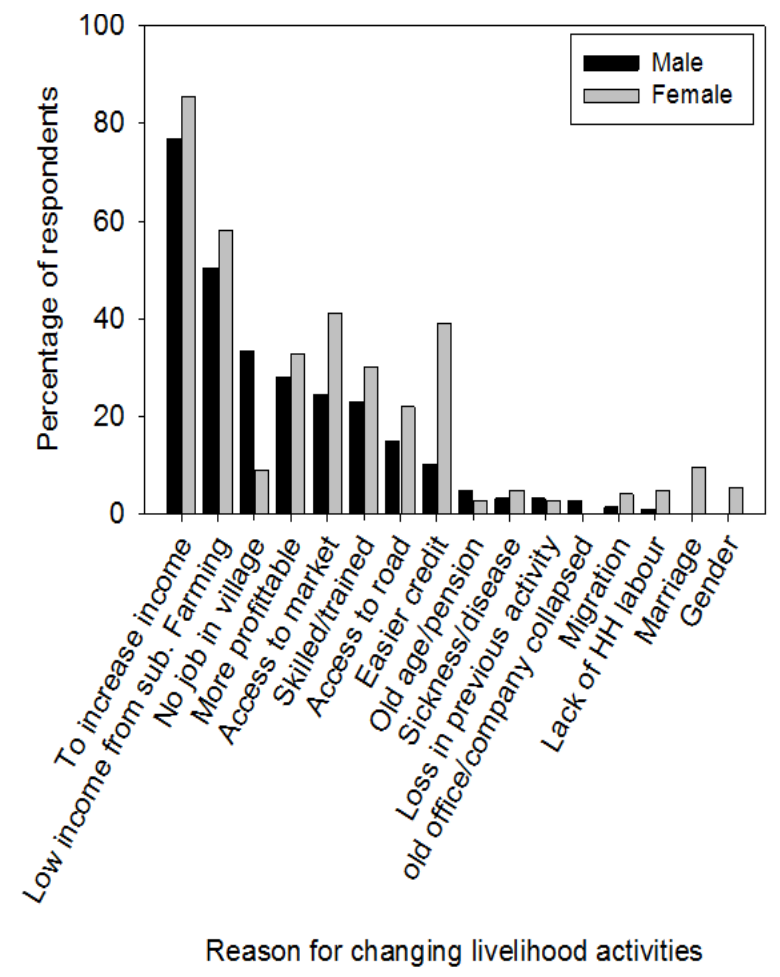

Figure 3. Reasons for changing major livelihood activities by males and females. (Note: one respondent answered multiple reasons. The percentages are derived from the total number of male and female respondents not from the total number of reasons). 
The results showed that among the total respondents of men $(\mathrm{N}=510)$ and women $(\mathrm{N}=146)$, the majority (more than $75 \%$ men and $85 \%$ women) have reported that they changed their previous activities in order to increase income. Similarly, about $50 \%$ men and $58 \%$ women stated low income from subsistence farming was one of the reasons for changing their activities. Increasing access to market was reported by about $25 \%$ men and $41 \%$ women, and increasing access to vehicle-passable roads by about $15 \%$ men and $22 \%$ of women as the factors encouraging the change in livelihood activities. Increased educational qualification/skills/training have caused about $23 \%$ of the men and $30 \%$ of women to change their livelihood activities. Easier access to credit was reported by $10 \%$ of male and $39 \%$ of female respondents as one of the reasons.

Various push and pull factors have been identified as the reasons for changing rural livelihood strategies [89]. The result of this study also demonstrated both the pull and push factors as reasons for changing livelihood activities by men and women. A majority of the respondents reported that the need to increase income, low income from subsistence farming, and lack of jobs in the village were major push factors for changing previously followed livelihood activities irrespective of gender. With some exceptions, people change their livelihood activities in order to pursue better livelihoods via increasing income [90]. Similarly, major pull factors were increasing access to markets and roads, easier credit, increasing educational qualification and access to skills and training for higher income. Strikingly, a higher percentage of women than men responded that they changed their previously followed livelihood activities due to easier access to credit. This could be due to the recently improving women-friendly financial policy of the government of Nepal creating easier environment for women and marginalized groups to get credit for establishing self-employed business and micro- enterprises without any mortgage. Moreover, it could be due to increasingly established co-operatives and women's saving groups that makes access to loans for women easier.

\subsection{Influencing Factors for Livelihood Activity Change to Higher-Returning Activities}

The relationship between the explanatory variables used in the binary logistic regression model and dependent variables (changed to higher-returning and changed to other) by gender is presented in Table 5. The results showed that the household-level characteristics (including ethnicity, agroecological regions, home-market distance, and home-road distance) of the men between the two groups were significantly different between adopters and non-adopters of higher-returning income activities. The individual characteristics (including relationship to household $(\mathrm{HH})$ head, education, skills/training, marital status, membership in group/organization, out-migration, access to loans, and age) were also significantly different among adopter and non-adopter groups (Table 5). In the case of women, the household-level characteristics (ethnicity, agroecological regions, home-market distance, and home-road distance) were significantly different between adopters and non-adopters. The individual characteristics (relationship to HH head, education, skills/training, marital status, membership in group/organization, out-migration, access to loans, and age) were also significantly different among adopters of higher-returning activities and non-adopters. 
Table 5. Summary statistics of explanatory variables for income activities' change to higher-returning and other activities by men and women. Results are derived from chi-square test for categorical variables and analysis of variance (ANOVA) test for the covariates.

\begin{tabular}{|c|c|c|c|c|c|c|c|}
\hline \multirow[b]{2}{*}{ Variables } & & \multicolumn{3}{|c|}{ Men } & \multicolumn{3}{|c|}{ Women } \\
\hline & & $\begin{array}{l}\text { Changed to Higher Returning } \\
\qquad(\mathrm{N}=148)\end{array}$ & $\begin{array}{l}\text { Changed to Other } \\
\quad(\mathrm{N}=362)\end{array}$ & Chi-Square & $\begin{array}{l}\text { Changed to Higher Returning } \\
(\mathrm{N}=79)\end{array}$ & $\begin{array}{l}\text { Changed to Other } \\
\qquad(N=67)\end{array}$ & Chi-Square \\
\hline $\mathrm{HH}$ Sex ${ }^{\mathrm{a}}$ & $\begin{array}{l}\text { Male headed } \\
\text { Female headed }\end{array}$ & $\begin{array}{l}30.1 \\
26.4\end{array}$ & $\begin{array}{l}69.9 \\
73.6\end{array}$ & 0.67 & $\begin{array}{l}47.7 \\
63.3\end{array}$ & $\begin{array}{l}52.3 \\
36.7\end{array}$ & $3.49 *$ \\
\hline Family type ${ }^{a}$ & $\begin{array}{l}\text { Nuclear family } \\
\text { Joint family }\end{array}$ & $\begin{array}{l}31.2 \\
27.2\end{array}$ & $\begin{array}{l}68.8 \\
72.8\end{array}$ & 0.95 & $\begin{array}{c}56 \\
52.1\end{array}$ & $\begin{array}{c}44 \\
47.9\end{array}$ & 0.222 \\
\hline HH ethnicity ${ }^{a}$ & $\begin{array}{c}\text { Dalit } \\
\text { Janajati } \\
\text { Tharu } \\
\text { Brahmin/Chhetri }\end{array}$ & $\begin{array}{l}28.8 \\
26.3 \\
16.5 \\
38.4\end{array}$ & $\begin{array}{l}71.2 \\
73.7 \\
83.5 \\
61.6\end{array}$ & $13.79 * *$ & $\begin{array}{l}47.1 \\
65.1 \\
65.5 \\
42.1\end{array}$ & $\begin{array}{l}52.9 \\
34.9 \\
34.5 \\
57.9\end{array}$ & $7.266^{*}$ \\
\hline $\mathrm{HH}$ religion ${ }^{\mathrm{a}}$ & $\begin{array}{l}\text { Other } \\
\text { Hindu }\end{array}$ & $\begin{array}{c}24.7 \\
30 \\
\end{array}$ & $\begin{array}{c}75.3 \\
70\end{array}$ & 1.06 & $\begin{array}{c}68 \\
51.2\end{array}$ & $\begin{array}{c}32 \\
48.8\end{array}$ & 2.344 \\
\hline Relationship to $\mathrm{HH}$ head ${ }^{\text {a }}$ & $\begin{array}{c}\text { HH head } \\
\text { Spouse } \\
\text { Son/Grand-son/daughter/grand-daughter } \\
\text { Daughter-in-laws }\end{array}$ & $\begin{array}{c}54.1 \\
38.6 \\
16.9 \\
-\end{array}$ & $\begin{array}{c}45.9 \\
61.4 \\
83.1 \\
-\end{array}$ & $\begin{array}{c}66.18^{* * * *} \\
- \\
-\end{array}$ & $\begin{array}{c}76.3 \\
74.1 \\
30.8 \\
40 \\
\end{array}$ & $\begin{array}{c}23.7 \\
25.9 \\
69.2 \\
60\end{array}$ & $21.994 * * *$ \\
\hline Marital status $^{\text {a }}$ & $\begin{array}{c}\text { Other } \\
\text { Married }\end{array}$ & $\begin{array}{l}16.4 \\
32.5 \\
\end{array}$ & $\begin{array}{l}83.6 \\
67.5 \\
\end{array}$ & $10.91^{* * * *}$ & $\begin{array}{l}74.6 \\
89.9 \\
\end{array}$ & $\begin{array}{l}25.4 \\
10.1 \\
\end{array}$ & $5.938^{* *}$ \\
\hline Skills/training a & $\begin{array}{l}\text { Yes } \\
\text { No }\end{array}$ & $\begin{array}{l}42.2 \\
19.7\end{array}$ & $\begin{array}{l}57.8 \\
80.3\end{array}$ & $30.26^{* * *}$ & $\begin{array}{c}72.6 \\
29\end{array}$ & $\begin{array}{c}27.4 \\
71\end{array}$ & $27.29^{* * *}$ \\
\hline Membership in group/organization ${ }^{a}$ & $\begin{array}{l}\text { Yes } \\
\text { No } \\
\end{array}$ & $\begin{array}{l}40.4 \\
10.7 \\
\end{array}$ & $\begin{array}{l}59.6 \\
89.3 \\
\end{array}$ & $51.79^{* * * *}$ & $\begin{array}{l}68.8 \\
36.4 \\
\end{array}$ & $\begin{array}{l}31.3 \\
63.6 \\
\end{array}$ & $15.28^{* * *}$ \\
\hline Out-migration $^{a}$ & $\begin{array}{l}\text { Yes } \\
\text { No }\end{array}$ & $\begin{array}{c}6.2 \\
55.7\end{array}$ & $\begin{array}{l}93.8 \\
44.3\end{array}$ & $151.12 * * *$ & $\begin{array}{l}33.3 \\
60.9\end{array}$ & $\begin{array}{l}66.7 \\
39.1\end{array}$ & $19.809^{* * *}$ \\
\hline Access to loan ${ }^{a}$ & $\begin{array}{l}\text { Yes } \\
\text { No }\end{array}$ & $\begin{array}{l}46.2 \\
12.9\end{array}$ & $\begin{array}{l}53.8 \\
87.1\end{array}$ & 68.27 & $\begin{array}{l}63.8 \\
29.3\end{array}$ & $\begin{array}{l}36.2 \\
70.7\end{array}$ & $8.31^{* *}$ \\
\hline Study villages ${ }^{a}$ & $\begin{array}{l}\text { Inner-terai VDC } \\
\text { Mid-hill VDC } \\
\text { High-hill VDC } \\
\end{array}$ & $\begin{array}{c}20.9 \\
48.4 \\
19 \\
\end{array}$ & $\begin{array}{c}79.1 \\
51.6 \\
81 \\
\end{array}$ & $42.38^{* * * *}$ & $\begin{array}{c}51.4 \\
55.3 \\
60 \\
\end{array}$ & $\begin{array}{c}48.6 \\
44.7 \\
40 \\
\end{array}$ & 0.61 \\
\hline \multicolumn{2}{|c|}{ Age (Years) ${ }^{b}$} & 42.8 & 31.4 & $114.02 * * *$ & 33.9 & 28.6 & $13.04^{* * *}$ \\
\hline \multicolumn{2}{|c|}{ Education (Years) ${ }^{\mathrm{b}}$} & 6.5 & 9.7 & $55.35^{* * *}$ & 5.4 & 11.1 & $54.15^{* * *}$ \\
\hline \multicolumn{2}{|c|}{ Home-market distance $(\mathrm{km})^{\mathrm{b}}$} & 4.6 & 7 & $22.9^{* * *}$ & 5.4 & 6.6 & $4.76^{* *}$ \\
\hline Home-road & istance $(\mathrm{km})^{\mathrm{b}}$ & 0.3 & 0.5 & $12.09^{* * * *}$ & 0.3 & 0.5 & $8.81^{* *}$ \\
\hline
\end{tabular}

${ }^{* * *}$ Significant at $1 \%, * * 5 \%,{ }^{*} 10 \%{ }^{\text {a }}$ nominal variables: results are derived from chi-square test; ${ }^{\mathrm{b}}$ continuous variable: results are F-values derived from analysis of variance (ANOVA). 


\subsection{Determinants of Changing Livelihood Activities to Higher Returning Activities}

Many explanatory variables included in the model did not show a differential influence between men's and women's behavior to switch to higher-returning activities (Table 6). Except for a few of them, these variables tend to have a similar direction of influence in men's and women's changing behavior. Personal characteristics including age, education, status of skills and training, and access to loans significantly influenced the change of livelihood activities from lower-returning to higher-returning activities for both men and women, while marital status and membership in organizations significantly influenced men's behavior but did not influence women's behavior (Table 6). The age of an individual was found to be positively and significantly associated with the behavior of switching to higher-returning activities while the number of years of formal education was found to be negatively associated for both genders. The relation of age and education with an individual's choice to enter business/enterprise activities remain dubious in the available literature [70-73]. This result is consistent with Simoes's [72] finding which also revealed a positive relationship between age and livelihood activity change to higher-returning activities. Confirming Johansson's [73] finding, the result of this study showed a negative association between education and income activities' shift to higher-returning activities for both men and women. This result could be due to the increasing out-migration of rural youth with higher education to cities and abroad, family farming and other business/enterprise activities have been shifting to the hands of less educated older people. Moreover, in general older individuals in Nepalese households have more access to and control over financial resources that may ease them to invest in market-oriented farm and non-farm business enterprises.

The result of this study showed that skills and training acquired by an individual significantly $(p=0.001)$ increase the likelihood of changing to higher-returning activities by men and women. This result supports Mohapatra's [91] finding in China who found a strong influence of skills and training of an individual in the adoption of higher-returning enterprises. Providing agricultural and other self-employment training to rural people produces better-qualified and more productive farmers/entrepreneurs with adaptation skills to changing markets [92]. During FGDs and key informant surveys, the participants reported that increasing access to agricultural and other income-generating training provided by various development programmes have stimulated men and women to enter commercially oriented high-value crop (vegetables, tea and coffee production) and livestock production (poultry, cow and goat farm, pig farm, beekeeping and fish farming) and other non-farm enterprises in the study villages. Access to loans as a proxy of financial capital, as shown by the result in Table 6 , had a significant positive ( $p=0.001$ for men and $p=0.01$ for women) relation to changing livelihood activity to higher-returning activities irrespective of gender. The significant role of credit for the rural poor to enter commercially oriented farm and non-farm enterprises has been highlighted by several previous studies $[78,79,93]$. A positive relation between access to loans and the shift of previous activities to higher-returning activities in the result could be due to increasing access to micro-credit from banks and co-operatives, loans from self-help groups and women's groups supporting poor men and women to start up new businesses and enterprises in the study villages. In the FGDs, participants reported that their access to loans has increased in comparison to 10 years ago.

Men having membership in the formal or informal group or organizations were more likely to switch to higher-returning activities while this had no significant influence on women. This may be due to the ineffectiveness of women's groups to encourage the members to start entrepreneurship compared to men's groups. Smith [70] concluded that membership of group/organization increases the likelihood of entering business/enterprise activities; however, it was not a gender-disaggregated analysis. Similarly, out-migration had a negative relationship with changing to higher-returning activities in the case of men. It is reasonable for people who are living in the villages have been trying to supplement their income by diversifying their subsistence farming to market-oriented cash crop and livestock production and by establishing non-farm business in the potential areas. In the case of men, relationship to household head was also found to be a determinant for switching to higher-returning activities. Where the household head is a woman, her husband is less likely to switch 
to higher-returning activities. However, the position of a person in household was not a significant determinant in the case of women. This may be because when the husband is less likely to switch to higher-returning jobs, women tend to take the household head's role.

Distance to market-center and distance to the nearest vehicle-passable road from the house both influenced negatively and significantly switching behaviour to the higher-returning activities for both men and women. Paudel Khatiwada's [48] and Soltani's [94] studies also found the similar influences of distance to markets and vehicle-passable roads in choosing a higher-returning livelihood strategy. It could be because a nearer distance to road and market center decreases the production cost and increases the market opportunities for the produced goods. Participants in the FGDs and key informant interviews in the three VDCs also reported that in comparison to 10 years ago, there is greater involvement of men and women in market-oriented high-value crop (including vegetables, fruits, tea and coffee) and livestock (including poultry, cow and goat farm, fish farm, pig farm, bee-keeping) production along with non-farm business and self-employed enterprises (including small grocery shop, hotel, restaurants, and other self-employed repairing centers, tailoring, beauty shop).

Similar to the previous studies $[48,76,78]$, agro-ecology was found to be the important determinant $(p=0.001)$ for switching to higher-returning activities for both men and women. It is also found that an increase in elevation increases the likelihood of entering non-farm business/enterprises related strategies $[48,76]$. The result in this study also demonstrated that both men and women in mid-hills and low-hills are less likely to switch to higher-returning activities than people in the high hills. This behavior was found to be similar for both genders. As reported by the participants in FGDs and key informant interviews, the involvement of local people in the production of market-oriented high-value cash crops (vegetables, tea and coffee) and livestock (goat and sheep farm, cow farm and poultry farm) has been increasing in recent years in the high hill VDC (Ghanpokhra in Lamjung district). Meantime, this VDC has been developing as a center of eco-tourism where local peoples are encouraged to start tourism-related business/enterprises. Moreover, among the out-migrants, younger men and women, some have established their own business in the cities. Given such recently emerging newer livelihood opportunities in the high hill VDC, the likelihood of change to non-farm activities is higher for both men and women in comparison to mid-hill and low-land terai. While low-land and mid-hill villages have more potential in agriculture and the majority of them involved in subsistence farming. In addition, these villages have better infrastructures development and have higher connectivity with the major cities. Hence, the possibility of becoming involved in salaried jobs and wage labor activities is higher reducing the potential for involvement in self-employed and business activities.

The result showed that ethnicity is significant determinant $(p=0.010)$ for switching to higher-returning activities for women, but it was not significant determinant for men. This result not only explains Paudel Khatiwada's [48] findings with a higher likelihood of Dalit, Janajati and Tharu ethnic group to switch to higher-returning activities but also highlights that women in these ethnic groups are more likely to change their livelihood to higher-returning activities. The possible reason behind this result could be social restrictions and taboos for women in the Janajati (including Newars, Gurung, Magar) and Tharu communities becoming more relaxed and they have more access to resources and benefits and decision-making power compared to Brahmin/Chhetri women. Therefore, women from those ethnic communities are more likely to have been involved in business/enterprise-related activities for a long time [86]. In addition, the ongoing social and political transformation and women's empowerment programs in the rural areas of Nepal have been improving the situation of Janajati and aboriginal women. Similar differences can be seen in case of marital status. In the case of men, there was a significant and positive relationship between 'being married' and likelihood of switching to higher-income activities, but this association was not significant for women. This may be because, in patriarchal norms, husbands are regarded as the breadwinner for the households, which compels young men to start earning a higher amount of money after getting married. 
Table 6. Determinants of income activities' change to higher-returning activities by men and women (binary regression model).

\begin{tabular}{|c|c|c|c|}
\hline & & Men & Women \\
\hline Variables & Categories & $\beta(\mathrm{SE})$ & $\beta(\mathrm{SE})$ \\
\hline HH sex & Female headed ${ }^{a b}$ & $-0.09(0.45)$ & $0.76(1.00)$ \\
\hline Family type & Nuclear family ac & $0.07(0.34)$ & $-0.15(0.65)$ \\
\hline Ethnicity & $\begin{array}{l}\text { Dalit ad } \\
\text { Janajati ad } \\
\text { Tharu ad }\end{array}$ & $\begin{array}{l}-0.21(0.5) \\
-0.04(0.41) \\
-0.26(0.5)\end{array}$ & $\begin{array}{l}0.58(1.27) \\
3.02(1.03)^{\text {** }} \\
2.22(0.94)^{* *}\end{array}$ \\
\hline Religion & Hindu ae & $0.8(0.57)$ & $-0.74(1.12)$ \\
\hline Relationship to HH head & $\begin{array}{l}\text { HH head af } \\
\text { Spouse af } \\
\text { Son/grand-son } \\
\text { daughter/grand-daughter af } \\
\text { Daughter-in-Law }\end{array}$ & $\begin{array}{l}-0.67(0.52) \\
-1.17(0.69)^{*} \\
()\end{array}$ & $\begin{array}{l}1.05(1.25) \\
-0.65(1.22) \\
-0.79(0.94)\end{array}$ \\
\hline Marital status & Married ag & $0.84(0.45)^{*}$ & () \\
\hline Age & & $0.04(0.02) * *$ & $0.11(0.06)^{* *}$ \\
\hline Education & & $-0.08(0.04) *$ & $-0.16(0.09)^{* *}$ \\
\hline Skills and training & Skilled/trained ah & $1.03(0.3)^{* * *}$ & $2.24(0.66)^{* * *}$ \\
\hline Membership in group/organization & Having membership ai & $1.48(0.38)^{* * * *}$ & $0.16(0.81)^{* *}$ \\
\hline Access to loan & Having access to loan aj & $1.15(0.34)^{* * * *}$ & $2.54(0.93) * *$ \\
\hline Out-migration & Migration to abroad/cities ak & $-2.38(0.37)^{* * *}$ & $-1.08(0.89)$ \\
\hline Geographical location & $\begin{array}{l}\text { Low-land terai VDC al } \\
\text { Mid-hill VDC al }\end{array}$ & $\begin{array}{l}-3.08(0.74)^{* * *} \\
-0.89(0.8)\end{array}$ & $\begin{array}{l}-6.61(2.46)^{* *} \\
-4.7(2.34)^{* *}\end{array}$ \\
\hline Home-market distance $\mathrm{km}$ & & $-0.16(0.07)^{* *}$ & $-0.33(0.16)^{* *}$ \\
\hline \multirow[t]{2}{*}{ Home-road distance $\mathrm{Kr}$} & & $-1.12(0.37)^{* *}$ & $-1.17(0.69)^{*}$ \\
\hline & & $\begin{array}{l}\text { Model summary Male: Hosmer and Lemeshow Test: } \\
\text { Chi-square }=5.47 ; \mathrm{df}=8 ; \text { Sig }=0.71 ;-2 \text { Log likelihoods }=315.421 ; \\
\text { Cox \& Snell R Square }=0.54 ; \text { Nagelkerke R Square = } 0.72 ; \text { Overall } \\
\text { Percentage explained }=88.4\end{array}$ & $\begin{array}{l}\text { Model Summary Female: Hosmer and Lemeshow Test: } \\
\text { Chi-square }=1.92 ; \mathrm{df}=8 \text {; Sig. }=0.98 ;-2 \text { Log likelihood }=89.684 ; \\
\text { Cox \& Snell R Square }=0.54 ; \text { Nagelkerke R Square }=0.72 ; \\
\text { Overalpercentage explained }=87.0\end{array}$ \\
\hline
\end{tabular}


The results in this study have shown that non-farm-based cash-earning activities including business, salaried jobs, foreign jobs and wage labour non-farm activities are dominated by men while farming activities by women in the study sites. This is an indication of gender difference in the choice of livelihood activities in rural households in Nepal. Tamang's study (59) and Gartaula's study (95) also highlighted an increasing feminization of agriculture due to the increasing outmigration of men in rural households in Nepal. This study reveals that both men and women have been changing their livelihood activities from subsistence to cash-earning activities in the last decade. However, the livelihood activities of men have changed greatly compared to women. Furthermore, the changing pattern reveals that men are primarily attracted to out-migration and non-farm wage-based jobs whereas women to market-oriented commercial farming and self-employed enterprises. Remarkably, the proportion of women switching to higher-returning activities is exceptionally higher compared to men though fewer women have changed their livelihood activities than their male counterparts. This is a positive indication that the passive role of rural women in the household economy is now changing, albeit at a slow pace. As shown by the results, farm enterprises such as commercial vegetable and livestock faming, and non-farm income-generating activities such as tailoring, embroidery, local tea shops and restaurants, beauty parlors etc. have attracted rural women in the recent decade. The improving profitability of these enterprises can encourage more rural women to become involved in them which can lead to inclusive economic growth. Likewise, increasing attraction of the men towards non-farm activities including foreign jobs, salaried jobs and wage labour showed a broader and diversified economic options for men compared to their female counterparts. However, the increasing involvement of men in non-farm activities particularly out-migration has negative consequences on the socio-cultural, environmental, food security and health and wellbeing factors of those left behind in rural Nepal $[59,95-97]$. Hence, along with women the increasing interest of the men toward farm and non-farm rural enterprises is essential for the sustainable economic development of rural Nepal. This study shows that more women in the Janajati and Dalit ethnic groups have been shifting to higher-returning activities compare to Brahmin/Chhetri women. Providing similar opportunities for the women in every ethnicity may lead to the equitable economic empowerment of women in Nepal. Education, skills and trainings, access to credit, membership in organizations, access to roads and markets are recognized as the major influencing factors for switching livelihoods to higher-returning activities regardless of gender. However, strengthening human and financial capital along with increasing the connectivity of rural people to the global market irrespective of gender have become a recent policy challenge for attaining inclusive economic growth in rural Nepal.

\section{Summary and Conclusions}

This paper examined the status and trend of change in livelihood activities for rural men and women in Nepal and identified the determinants through gender-disaggregated analysis at the intra-household level. This study highlights an increasing feminization of agriculture in Nepal since the result showed a higher number of women continue to depend on farm-based livelihood activities compared to men. Although both men and women are switching their livelihood from subsistence farming to cash-earning activities, market-oriented commercial vegetable, livestock farming, and rural enterprises are becoming attractions for women. This study identified various push and pull factors for the change in livelihood activities of men and women. Finally, this study concluded individual, household and location-specific factors influence the switching of livelihood activities from low-returning to higher-returning activities differentially for men and women. Such a gender-disaggregated livelihood analysis is new and very timely for the changing socio-economic and political context of rural Nepal. This study enriches the literature with a gender-disaggregated study of changing livelihoods and provides empirical evidence on the status, trend and determinants of changing livelihoods among men and women in the central Nepal. The findings from the study are useful for deriving inclusive economic growth, poverty reduction and improving the economic conditions of women in central Nepal and in the other areas of Nepal with similar contexts. 
- Targeted programmes to encourage rural men and women to enter higher-returning income activities should emphasize building human capital through education, agriculture and skill-based training along with strengthening access to credit. Development policy should provide rural credit to the targeted group including women and marginalized to motivate them to change their traditional subsistence-oriented activities to more profitable market-oriented activities. These efforts, however, should go together with investment in rural infrastructure, particularly agricultural roads and market centres to increase the connectivity of the rural poor to the global market. Although the level of impact may vary between men and women, these interventions would have positive impacts on livelihood of both groups.

- Self-employment and market-oriented farming such as commercial vegetable and livestock keeping are the major source of employment for rural women. Therefore, improving the profitability of these enterprises is important for improving the welfare of women and their families. Therefore, interventions for promoting improved production technologies and enhancing market and value chains of these commodities would be a greater solution for reducing rural poverty and livelihood improvements of women and their families.

- Since a higher number of women are attracted to market-oriented commercial agriculture, they are also vulnerable to health hazards caused by insecticides and pesticides. To reduce the negative impacts of agro-chemicals on the health of women, a public extension system should implement programs to enhance knowledge and skills for safe and judicious use of agro-chemicals focusing on women farmers who have switched to commercial farming.

- Lack of interest among men in self-employment and rural enterprise is a challenge for the rural development of Nepal. While the migrating men bring a valuable amount of remittances to rural areas, the government should create an environment for using the remittances for more productive work. Support and subsidies for large-scale farms, plantations or livestock can be effective for productive use of remittances.

This study has drawn its conclusion based on the purposively selected three sample sites along an elevation gradient of the central landscape of Nepal using cross-sectional survey data based on recall-based information. While considering the diverse livelihood scenarios of Nepal, a gender-disaggregated study on changing livelihood activities in the future allocating sample sites from the whole of Nepal would provide more valid and robust results. Moreover, if longitudinal data are available in the future, the study could explore the causal relationship between certain socioeconomic factors and livelihood activities by using use some panel techniques.

Author Contributions: Conceptualization, S.P.K.; Data curation, S.P.K.; Formal analysis, S.P.K.; Funding acquisition, W.D.; Investigation, S.P.K., B.P., J.R.K. and J.Z.; Methodology, S.P.K., B.P. and J.R.K.; Project administration, W.D., S.P.K. and J.W.; Software, J.R.K.; Supervision, W.D.; Writing-original draft, S.P.K.; Writing-review and editing, W.D., B.P., J.R.K. and J.W.

Funding: This research was funded by NSFC-ICIMOD Cooperation Project (NO. 41661144038), Aid project on Ministry of Science and technology of the PRC in 2013, The World Academy of Sciences (TWAS) and CAS-TWAS President Fellowship Program.

Acknowledgments: We would like to acknowledge the support from NSFC-ICIMOD Cooperation Project (NO. 41661144038), Aid project on Ministry of Science and technology of the PRC in 2013, The World Academy of Sciences (TWAS) and CAS-TWAS President Fellowship Program. We would like to thank three anonymous reviewers for their invaluable comments on the manuscript that greatly improved the quality of this manuscript. In addition, farmers and local assistants in Bachhauli, Ghyalchok, and Ghanpokhara VDCs are thanked for their hospitality and support for completing the survey. Similarly, we thank the students of the Institute of Agriculture, Tribhuvan University, Rampur, Nepal, who were involved in household questionnaire survey.

Conflicts of Interest: The authors declare no conflict of interest. 


\section{References}

1. Ellis, F. Rural Livelihoods and Diversity in Developing Countries; Oxford University Press: Oxford, UK, 2000.

2. Berdegué, J.A.; Rosada, T.; Bebbington, A.J. The rural transformation. In International Development: Ideas, Experience, and Prospects; Currie-Alder, B., Kanbur, R., Malone, D.M., Medhora, R., Eds.; Oxford University Press: London, UK, 2014; p. 44.

3. Ilbery, B. Dimensions of rural change. In The Geography of Rural Change; Ilbery, B., Ed.; Routledge: London, UK, 2014; p. 10.

4. Borras, S.M., Jr. Agrarian change and peasant studies: Changes, continuities and challenges-An introduction. J. Peasant Stud. 2009, 36, 5-31. [CrossRef]

5. Adriansen, H.K. Continuity and change in pastoral livelihoods of Senegalese Fulani. Agric. Hum. Values 2006, 23, 215-229. [CrossRef]

6. Mushongah, J.; Scoones, I. Livelihood change in rural Zimbabwe over 20 years. J. Dev. Stud. 2012, 48, 1241-1257. [CrossRef]

7. Wang, C.; Yang, Y.; Zhang, Y. Economic development, rural livelihoods, and ecological restoration: Evidence from China. AMbio 2011, 40, 78-87. [CrossRef] [PubMed]

8. Castles, S.; De Haas, H.; Miller, M.J. The Age of Migration: International Population Movements in the Modern World, 5th ed.; Palgrave Macmillan: New York, NY, USA, 2013.

9. Gentle, P.; Maraseni, T.N. Climate change, poverty and livelihoods: Adaptation practices by rural mountain communities in Nepal. Environ. Sci. Policy 2012, 21, 24-34. [CrossRef]

10. Kangalawe, R.; Lyimo, J. Population dynamics, rural livelihoods and environmental degradation: Some experiences from Tanzania. Environ. Dev. Sustain. 2010, 12, 985-997. [CrossRef]

11. Rigg, J. Land, farming, livelihoods, and poverty: Rethinking the links in the rural south. World Dev. 2006, 34, 180-202. [CrossRef]

12. Chambers, R. Rural Development: Putting the Last First; Routledge: Abingdon, UK, 2014.

13. Bhandari, P.B. Rural livelihood change? Household capital, community resources and livelihood transition. J. Rural Stud. 2013, 32, 126-136. [CrossRef] [PubMed]

14. Soini, E. Changing livelihoods on the slopes of mt. Kilimanjaro, tanzania: Challenges and opportunities in the chagga homegarden system. Agrofor. Syst. 2005, 64, 157-167. [CrossRef]

15. Donovan, J.; Poole, N. Changing asset endowments and smallholder participation in higher value markets: Evidence from certified coffee producers in Nicaragua. Food Policy. 2014, 44, 1-13. [CrossRef]

16. Shivakoti, G.P.; Schmidt-Vogt, D. Livelihood change and livelihood sustainability in the uplands of Lembang subwatershed, west Sumatra, Indonesia, in a changing natural resource management context. J. Environ. Manag. 2009, 43, 84-99.

17. Valbuena, D.; Groot, J.C.; Mukalama, J.; Gérard, B.; Tittonell, P. Improving rural livelihoods as a "moving target": Trajectories of change in smallholder farming systems of western Kenya. Reg. Environ. Chang. 2015, 15, 1395-1407. [CrossRef]

18. De Waroux, Y.L.P.; Chiche, J. Market integration, livelihood transitions and environmental change in areas of low agricultural productivity: A case study from Morocco. Hum. Ecol. 2013, 41, 535-545. [CrossRef]

19. Niehof, A. The significance of diversification for rural livelihood systems. Food Policy 2004, 29, 321-338. [CrossRef]

20. Mehar, M.; Mittal, S.; Prasad, N. Farmers coping strategies for climate shock: Is it differentiated by gender? J. Rural Stud. 2016, 44, 123-131. [CrossRef]

21. Valdivia, C.; Gilles, J. Gender and resource management: Households and groups, strategies and transitions. Agric. Hum. Values 2001, 18, 5-9. [CrossRef]

22. Mainlay, J.; Tan, S.F. Mainstreaming Gender and Climate Change in Nepal; Climate Change; Working Paper; International Institute for Environmental Development (IIED): London, UK, 2012.

23. Kabeer, N. Reversed Realities: Gender Hierarchies in Development Thought; Verso: London, UK, 1994; p. 340.

24. Momsen, J. Women and Development in the Third World; Routledge: London, UK; New York, NY, USA, $2008 ;$ p. 112.

25. Kelkar, G. At the Threshold of Economic Empowerment: Women, Work and Gender Regimes in Asia; International Labour Organization: New Delhi, India, 2013; p. 43.

26. Eneyew, A.; Mengistu, S. Double marginalized livelihoods: Invisible gender inequality in pastoral societies. Societies 2013, 3, 104-116. [CrossRef] 
27. Denton, F. Climate change vulnerability, impacts, and adaptation: Why does gender matter? Gender Dev. 2002, 10, 10-20. [CrossRef]

28. Whitehead, A.; Kabeer, N. Living with Uncertainty: Gender, Livelihoods and Pro-Poor Growth in Rural Sub-Saharan Africa; Institute of Development Studies: Brighton, UK, 2001.

29. Quisumbing, A.R.; Rubin, D.; Manfre, C.; Waithanji, E.; van den Bold, M.; Olney, D.; Johnson, N.; Meinzen-Dick, R. Gender, assets, and market-oriented agriculture: Learning from high-value crop and livestock projects in Africa and Asia. Agric. Hum. Values 2015, 32, 705-725. [CrossRef]

30. Zakaria, H.; Abujaja, A.M.; Adam, H.; Salifu, W.Y. Does gender makes any difference in livelihoods diversification? Evidence from northern Ghana. J. Agric. Ext. Rural Dev. 2015, 1, 36-51.

31. Zakaria, H. The drivers of women farmers' participation in cash crop production: The case of women smallholder farmers in northern Ghana. J. Agriic. Educ. Ext. 2017, 23, 141-158. [CrossRef]

32. Mandel, J.L. Mobility matters: Women's livelihood strategies in Porto novo, Benin. Gender Place Cult. 2004, 11, 257-287. [CrossRef]

33. Maina, J.; Mbuthia, P.; Ngugi, J.; Omolo, B.; Orina, P.; Wangia, S.; Karuri, E.; Maitho, T.; Owiti, G. Influence of social-economic factors, gender and the fish farming enterprise and productivity project on fish farming practices in Kenya. Livest. Res. Rural Dev. 2014, 26, 2.

34. Development Bank (ADB). Gender Equality and Women's Empowerment: Operational Plan, 2013-2020: Moving the Agenda Forward in Asia and the Pacific; 978-92-9254-158-3; Asian Development Bank: Makati, Phillipines, 2013; p. 47.

35. Klugman, J.; Hanmer, L.; Twigg, S.; Hasan, T.; McCleary-Sills, J.; Santamaria, J. Voice and Agency: Empowering Women and Girls for Shared Prosperity; 978-1-4648-0359-8; World Bank Group: Washington, DC, 2014; p. 239.

36. Ministry of Finance (MoF). Nepal Economic Survey Report 2017-18; Government of Nepal, Ministry of Finance: Kathmandu, Nepal, 2018.

37. National Planning Commission (NPC). National Review of Sustainable Development Goals; Government of Nepal, National Planning Commission: Kathmandu, Nepal, 2017.

38. Geiser, A. Social Exclusion and Conflict Transformation in Nepal: Women, Dalit and Ethnic Groups Fast Country Risk Profile Nepal; Swisspeace: Bern, Switzerland, 2005.

39. Pasipanodya, T. A deeper justice: Economic and social justice as transitional justice in Nepal. Int. J. Transit. Justice 2008, 2, 378-397. [CrossRef]

40. Nightingale, A.J. Bounding difference: Intersectionality and the material production of gender, caste, class and environment in Nepal. Geoforum 2011, 42, 153-162. [CrossRef]

41. Upadhya, S. The status of women in Nepal-15 years on. Stud. Nepali Hist. Soc. 1996, 1, 423-453.

42. National Planning Commission (NPC). Nepal status paper-United nations conference on sustainable development 2012 (rio+20) synopsis. In United Nations Conference on Sustainable Development 2012 (Rio+20); National Planning Commission: Kathmandu, Nepal, 2011.

43. Sapkota, M. Emerging ethnic movements and contested rural development in Nepal. In Contested Development in Nepal: Experiences and Reflections; Sharma, S.R., Manandhar, P., Sapkota, M., Eds.; School of Arts, Kathmandu University and Nepal Centre for Contemporary Research: Kathmandu, Nepal, 2014; pp. 77-105.

44. Bhattarai, D. Nepal: Changing political economy. Int. J. Commer. Manag. 2001, 11, 50-69. [CrossRef]

45. Acharya, S. Pro-Poor Growth and Liberalization in Developing Economies: The Case of Nepal; Routledge: London, UK, 2013; p. 240.

46. Bartlett, R.; Bharati, L.; Pant, D.; Hosterman, H.; McCornick, P.G. Climate Change Impacts and Adaptation in Nepal; IWMI: Colombo, Sri Lanka, 2010; Volume 139.

47. Intergovernmental Panel on Climate Change (IPCC). Climate Change 2007: Impacts, Adaptation and Vulnerability: Contribution of Working Group II to the Fourth Assessment Report of the Intergovernmental Panel on Climate Change; Cambridge University Press: Cambridge, UK, 2007; Volume 4.

48. Paudel Khatiwada, S.; Deng, W.; Paudel, B.; Khatiwada, J.R.; Zhang, J.; Su, Y. Household livelihood strategies and implication for poverty reduction in rural areas of central Nepal. Sustainability 2017, 9, 612. [CrossRef]

49. Blaikie, P.; Cameron, J.; Seddon, D. Understanding 20 years of change in west-central Nepal: Continuity and change in lives and ideas. World Dev. 2002, 30, 1255-1270. [CrossRef]

50. Poertner, E.; Junginger, M.; Müller-Böker, U. Migration in far west Nepal: Intergenerational linkages between internal and international migration of rural-to-urban migrants. Crit. Asian Stud. 2011, 43, 23-47. [CrossRef] [PubMed] 
51. Rahut, D.B.; Ali, A.; Kassie, M.; Marenya, P.P.; Basnet, C. Rural livelihood diversification strategies in Nepal. Poverty Public Policy 2014, 6, 259-281. [CrossRef]

52. Anup, K.; Parajuli, R.B.T. Tourism and its impact on livelihood in manaslu conservation area, Nepal. Environ. Dev. Sustain. 2014, 16, 1053-1063.

53. Raut, N.; Sitaula, B.K.; Bajracharya, R.M. Agricultural intensification: Linking with livelihood improvement and environmental degradation in mid-hills of Nepal. J. Agric. Environ. 2010, 11, 83-94. [CrossRef]

54. Nepal, R.; Thapa, G.B. Determinants of agricultural commercialization and mechanization in the hinterland of a city in Nepal. Appl. Geogr. 2009, 29, 377-389. [CrossRef]

55. Brown, S.; Kennedy, G. A case study of cash cropping in Nepal: Poverty alleviation or inequity? Agric. Hum. Values 2005, 22, 105-116. [CrossRef]

56. Ministry of Finance (MoF). Nepal Economic Survey Report 2012-13; Government of Nepal, Ministry of Finance: Kathmandu, Nepal, 2013.

57. CBS. Agriculture Census 2011; Government of Nepal: Kathmandu, Nepal, 2011.

58. Onta, N.; Resurreccion, B.P. The role of gender and caste in climate adaptation strategies in Nepal: Emerging change and persistent inequalities in the far-western region. Mt. Res. Dev. 2011, 31, 351-356. [CrossRef]

59. Tamang, S.; Paudel, K.P.; Shrestha, K.K. Feminization of agriculture and its implications for food security in rural Nepal. J. For. Livelihood 2014, 12, 20-32.

60. Chambers, R.; Conway, G. Sustainable Rural Livelihoods: Practical Concepts for the 21st Century; Institute of Development Studies: Brighton, UK, 1992.

61. Alderman, H.; Chiappori, P.-A.; Haddad, L.; Hoddinott, J.; Kanbur, R. Unitary versus collective models of the household: Is it time to shift the burden of proof? World Bank Res. Obs. 1995, 10, 1-19. [CrossRef]

62. Krantz, L. The Sustainable Livelihood Approach to Poverty Reduction; SIDA, Division for Policy and Socio-Economic Analysis: Stockholm, Sweden, 2001.

63. Savath, V.; Fletschner, D.; Peterman, A.; Santos, F. Land, Assets, and Livelihoods: Gendered Analysis of Evidence from Odisha State in India; IFPRI Discussion Paper 01323; International Food Policy Research Institute (IFPRI): Washington, DC, USA, 2014; p. 36.

64. Meinzen-Dick, R.; Johnson, N.; Quisumbing, A.R.; Njuki, J.; Behrman, J.A.; Rubin, D.; Peterman, A.; Waithanji, E. The Gender Asset Gap and Its Implications for Agricultural and Rural Development. In Gender in Agriculture; Quisumbing, A., Meinzen-Dick, R., Raney, T., Croppenstedt, A., Behrman, J., Peterman, A., Eds.; Springer: Dordrecht, The Netherlands, 2014; pp. 91-115.

65. Department for International Development (DFID). Sustainable Livelihoods Guidance Sheets; Department for International Development: London, UK, 1999.

66. WWF Nepal. Chitwan Annapurna Landscape (Chal): A Rapid Assessment; WWF: Kathmandu, Nepal, August 2013.

67. Paudel Khatiwada, S.; Zhang, J.; Yi, S.; Paudel, B.; Deng, W. Agricultural land use intensity and determinants in different agro-ecological regions of central Nepal. In Land Cover Change and Its Eco-Environmental Responses in Nepal; Li, A., Wei, D., Wei, Z., Eds.; Springer: Chengdu, China, 2017; pp. 281-305.

68. Kura, Y.; Joffre, O.; Laplante, B.; Sengvilaykham, B. Coping with resettlement: A livelihood adaptation analysis in the Mekong river basin. Land Use Policy 2017, 60, 139-149. [CrossRef]

69. Kristjanson, P.; Krishna, A.; Radeny, M.; Kuan, J.; Quilca, G.; Sanchez-Urrelo, A.; Leon-Velarde, C. Poverty dynamics and the role of livestock in the Peruvian Andes. Agric. Syst. 2007, 94, 294-308. [CrossRef]

70. Smith, D.R.; Gordon, A.; Meadows, K.; Zwick, K. Livelihood diversification in Uganda: Patterns and determinants of change across two rural districts. Food Policy 2001, 26, 421-435. [CrossRef]

71. Giannetti, M.; Simonov, A. On the determinants of entrepreneurial activity: Social norms, economic environment and individual characteristics. Swedish Econ. Policy Rev. 2004, 11, 269-313. [CrossRef]

72. Simoes, N.; Crespo, N.; Moreira, S.B. Individual determinants of self-employment entry: What do we really know? J. Econ. Surv. 2016, 30, 783-806. [CrossRef]

73. Johansson, E. Self-employment and liquidity constraints: Evidence from Finland. Scand. J. Econ. 2000, 102, 123-134. [CrossRef]

74. Dixon-Mueller, R.B. Rural Women at Work: Strategies for Development in South Asia; Routledge: London, UK, 2013.

75. Mwangi, M.N.; Ngigi, M.; Mulinge, W. Gender and age analysis on factors influencing output market access by smallholder farmers in Machakos county, Kenya. Afric. J. Agric. Res. 2015, 10, 3840-3850.

76. Jansen, H.G.; Pender, J.; Damon, A.; Wielemaker, W.; Schipper, R. Policies for sustainable development in the hillside areas of Honduras: A quantitative livelihoods approach. Agric. Econ. 2006, 34, 141-153. [CrossRef] 
77. Gautam, Y.; Andersen, P. Rural livelihood diversification and household well-being: Insights from Humla, Nepal. J. Rural Stud. 2016, 44, 239-249. [CrossRef]

78. Brown, D.R.; Stephens, E.C.; Ouma, J.O.; Murithi, F.M.; Barrett, C.B. Livelihood Strategies in the Rural Kenyan Highlands; Cornell University: Ithaca, NY, USA, 2006.

79. Hill, R.V.; Vigneri, M. Mainstreaming Gender Sensitivity in Cash Crop Market Supply Chains. In Gender in Agriculture; Quisumbing, A., Meinzen-Dick, R., Raney, T., Croppenstedt, A., Behrman, J., Peterman, A., Eds.; Springer: Dordrecht, The Netherlands, 2014.

80. Acharya, D.R.; Bell, J.S.; Simkhada, P.; Van Teijlingen, E.R.; Regmi, P.R. Women's autonomy in household decision-making: A demographic study in Nepal. Reprod. Health 2010, 7, 15. [CrossRef] [PubMed]

81. Gondal, A.H. Women's involvement in earning activities: Evidence from rural Pakistan. Lahore. J. Econ. 2003, 8, 123-136.

82. Nielsen, Ø.J.; Rayamajhi, S.; Uberhuaga, P.; Meilby, H.; Smith-Hall, C. Quantifying rural livelihood strategies in developing countries using an activity choice approach. Agric. Econ. 2013, 44, 57-71. [CrossRef]

83. Devkota, D.; Rauniyar, G.P.; Parker, W. The role of gender and ethnicity in household decision-making: Evidence from rural Nepal. In Proceedings of the Annual Confererence of the Australian Agricultural and Resource Economics Society, Christchurch, New Zealand, 20-22 January 1999.

84. Brown, S. Spatial analysis of socioeconomic issues: Gender and gis in Nepal. Mt. Res. Dev. 2003, 23, 338-344. [CrossRef]

85. Bhadra, C.; Shah, T.M. Nepal: Country Gender Profile; Japana International Cooperation Agency (JICA): Kathmandu, Nepal, 2007.

86. Bushell, B. Women entrepreneurs in Nepal: What prevents them from leading the sector? Gender Dev. 2008, 16, 549-564. [CrossRef]

87. Sati, M.C.; Juyal, R.P. A gender approach to sustainable rural development of mountains: Women's successes in agro-enterprises in the Indian central Himalayan region. Mt. Res. Dev. 2008, 28, 8-12. [CrossRef]

88. Murphy, H.H.; Sanusi, A.; Dilts, R.; Yuliatingsih, S.; Djajadisastra, M.; Hirschhorn, N. Health effects of pesticide use among Indonesian women farmers. J. Agromed. 2000, 6, 61-85. [CrossRef]

89. Barrett, C.B.; Reardon, T.; Webb, P. Nonfarm income diversification and household livelihood strategies in rural Africa: Concepts, dynamics, and policy implications. Food Policy 2001, 26, 315-331. [CrossRef]

90. Ellis, F. Household strategies and rural livelihood diversification. J. Dev. Stud. 1998, 35, 1-38. [CrossRef]

91. Mohapatra, S.; Rozelle, S.; Goodhue, R. The rise of self-employment in rural china: Development or distress? World Dev. 2007, 35, 163-181. [CrossRef]

92. Wallenborn, M. Skills development for poverty reduction (sdpr): The case of Tajikistan. Int. J. Educ. Dev. 2009, 29, 550-557. [CrossRef]

93. Francis, E. Gender and rural livelihoods in Kenya. J. Dev. Stud. 1998, 35, 72-95. [CrossRef]

94. Soltani, A.; Angelsen, A.; Eid, T.; Naieni, M.S.N.; Shamekhi, T. Poverty, sustainability, and household livelihood strategies in Zagros, Iran. Ecol. Econ. 2012, 79, 60-70. [CrossRef]

95. Gartaula, H.N.; Visser, L.; Niehof, A. Socio-cultural dispositions and wellbeing of the women left behind: A case of migrant households in Nepal. Soc. Indic. Res. 2012, 108, 401-420. [CrossRef] [PubMed]

96. Gartaula, H.N.; Niehof, A.; Visser, L. Feminisation of agriculture as an effect of male out-migration: Unexpected outcomes from jhapa district, eastern Nepal. Int. J. Interdiscip. Soc. Sci. 2010, 5, 565-577. [CrossRef]

97. Khanal, N.R.; Watanabe, T. Abandonment of agricultural land and its consequences: A case study in the sikles area, gandaki basin, nepal himalaya. Mt. Res. Dev. 2006, 26, 32-40. [CrossRef]

(C) 2018 by the authors. Licensee MDPI, Basel, Switzerland. This article is an open access article distributed under the terms and conditions of the Creative Commons Attribution (CC BY) license (http:// creativecommons.org/licenses/by/4.0/). 